\title{
Conexão Letras 量息

\section{DISCURSO DAS FAKE NEWS E SENTIDOS VIRAIS NO FUNCIONAMENTO E REPRODUÇÃO DO GÊNERO NORMATIVO}

\author{
FAKE NEWS DISCOURSE AND VIRAL SENSES IN THE FUNCTIONING AND
}

REPRODUCTION OF THE NORMATIVE GENRE

\author{
Sóstenes Ericson ${ }^{1}$ \\ Cíntia Ribeiro ${ }^{2}$
}

\begin{abstract}
Resumo: $\mathrm{O}$ avanço da propagação de fake news no período que antecedeu as eleições presidenciais norte-americanas, em 2016, e brasileiras, em 2018, coloca desafios importantes para os estudos sobre discurso, ideologia, sujeito e gênero em sua interface com a produção/reprodução de informação em ambientes digitais, conectados em redes on-line. A ancoragem no campo teórico da Análise do Discurso (AD) de filiação francesa pecheutiana possibilita analisar essa atualidade e a memória que a constitui, a partir da observação do funcionamento discursivo da mídia e das notícias falsas em espaços que, por serem "logicamente estabilizados", criam condições ideais para a circulação-proliferação, em larga escala, do que denominamos de "sentidos virais". O objetivo deste artigo é explicitar o papel da enunciação para tratar do funcionamento de questões de subjetivação em que se inscrevem as fake news, numa perspectiva heteronormativa universal e androcêntrica, impossibilitando, dessa maneira, deslocamentos nos processos de subjetivações de gênero. A análise possibilitou demonstrar que, enquanto tangencia identidades e subjetivações, o discurso político-religioso capitalista impõe uma noção de gênero e a regulação da sexualidade, no empreendimento da manipulação dos sentidos virais que regulam o gênero do capital.
\end{abstract}

Palavras-chave: Fake news. Gênero. Sentidos virais. Discurso. Mídias digitais.

\begin{abstract}
The advance of the spread of fake news in the period leading up to the North American presidential election, in 2016, and the Brazilian one, in 2018, poses important challenges for studies on discourse, ideology, subject and gender, in their interface with the production/reproduction of information in digital environments, connected in online networks. The anchoring in the theoretical field Analysis of Discourse (AD) of French affiliation by Michel Pêcheux, that enables the analysis of this news and the memory that constitutes it from the observation of the discursive functioning of the media and fake news in spaces that, for being "logically stabilized", create ideal conditions for circulation-proliferation, on a large scale, of what we call "viral senses" associated with non-binary genres. The purpose of this article was to make explicit the role of enunciation to deal with the functioning of subjectivation issues in which fake news is inscribed, in a universal and androcentric heteronormative perspective, thus making impossible to move displacements in the processes of gender subjetivations. The analysis demonstrates that while the capitalist political-religious discourse tangents on identities and subjectivations, imposes a notion of gender and the regulation of sexuality to achieve the manipulation of the viral senses that regulate the gender of capital.
\end{abstract}

Keywords: Fake news. Genre. Viral senses. Discourse. Digital media.

\section{Introdução}

\footnotetext{
${ }^{1}$ Doutor em Linguística pelo Programa de Pós-Graduação em Linguística e Literatura da Universidade Federal de Alagoas (UFAL). Coordena o projeto de pesquisa "Erro no trabalho em enfermagem: uma abordagem discursiva".

${ }^{2}$ Doutoranda no Programa de Pós-Graduação em Linguística e Literatura da Universidade Federal de Alagoas (UFAL). Vinculada ao projeto de pesquisa "Erro no trabalho em enfermagem: uma abordagem discursiva".
} 
A análise proposta neste artigo enfatiza a relação entre discurso, tecnologia e demanda social no funcionamento da produção/reprodução das fake news (notícias falsas) e tem por objetivo explicitar o papel da enunciação para tratar do funcionamento de questões de subjetivação em que se inscrevem as fake news, numa perspectiva heteronormativa universal e androcêntrica, impossibilitando, dessa maneira, deslocamentos nos processos de subjetivações de gênero. Observamos a circulação do que denominamos sentidos virais em espaços de discursividades "logicamente estabilizados" e que partem de uma "descrição adequada do universo (tal que este universo é tomado discursivamente)" (PÊCHEUX, 2015a, p. 31) nas instâncias moral, sexual, política e religiosa.

A expressão sentidos virais foi cunhada em analogia ao termo media viru $^{3}$ (RUSHKOFF, 1994). Enquanto, nos ambientes virtuais, o viral designa o volume massivo de propagação, o viral discursivo é acionado por mediações ideologicamente estabilizadas. Tecnicamente ancorado em sistemas de inteligência artificial, algoritmos, com propagação em hiperescala mecanizada - uso de perfis falsos, bots (robôs de internet) - em seu aspecto regulador, inscrevemos o sentido viral no escopo do que Pêcheux define como "objetos ideológicos regionais [...] Deus, a moral, a família" (2014, p. 132). Embora Pêcheux não trate propriamente das informações manipuladas, apresenta o sujeito pragmático, "cada um de nós", os usuários; e as "coisas a saber [...] conhecimentos a gerir e transmitir socialmente", representando valores morais impostos como verdade (2015a, p. 33, grifo do autor).

Nesse percurso teórico-analítico, tratamos o tecnológico enquanto meio de operacionalização do processo discursivo - produção de conteúdo descentralizada, distribuição instantânea, compartilhamento em diferentes mídias - das fake news. Concordamos com Pêcheux quando, ao discorrer sobre a aproximação entre os dispositivos técnicos e as demandas sociais, afirma que "as práticas técnicas são determinadas no sentido de receber da exterioridade uma demanda e são determinantes na medida em que é o conjunto das possibilidades que elas abrem que torna possível a existência da demanda" (PÊCHEUX, 1975 apud HENRY, 2014, p. 20).

Tomamos por recorte da materialidade linguístico-discursiva fake news que enunciavam, numa perspectiva normativa, os processos de produção/reprodução das subjetivações de gênero. O recorte para análise foi composto por texto e imagem: "Haddad diz que Estado decidirá o sexo das crianças: ‘Ao completar 5 anos de idade, a criança passa a

\footnotetext{
${ }^{3}$ Termo usado em analogia a conteúdos que se propagam como germes. Amplamente associado a contextos midiáticos, culturais e de marketing.

108 - Conexão Letras, Porto Alegre, v. 16, n. 25, p. 107-128, jan-jun. 2021.

E-ISSN 2594-8962. DOI: https://doi.org/10.22456/2594-8962.116834
} 
ser propriedade do Estado! Cabe a nós decidir se menino será menina e vice-versa! Aos pais cabe acatar nossa decisão respeitosamente! Sabemos o que é melhor para as crianças!'"4.

Veiculada no período que antecedeu as eleições presidenciais de 2018, a notícia falsa acima apresentada foi verificada pela Agência $\mathrm{Lupa}^{5}$, a partir de critérios de relevância (interesse público, alcance da circulação de sentido e/ou número de pessoas afetadas e legitimidade do enunciador). De acordo com o ranking da Agência Lupa de fact-checking (checagem $)^{6}$, a declaração, atribuída ao então candidato à presidência da República Fernando Haddad (PT), atingiu mais de 150 mil compartilhamentos nas redes sociais.

A partir do campo teórico da Análise do Discurso (AD) de filiação francesa, buscamos entender a complexidade discursiva nas plataformas on-line. Dessa maneira, este trabalho se configura no encontro de memórias (PÊCHEUX, 2015b), pois "até o fim se manifesta a paixão de Pêcheux pelas máquinas, o fascínio pela informática" (MALDIDIER, 2017, p. 107); e de atualidades, analisando a possibilidade de inscrição das fake news enquanto discurso e buscando entender os reflexos sem precedentes dessa inscrição no controle social do gênero e das configurações do real na sociedade contemporânea. Ao tratar dos efeitos de sentido que atravessam os processos de produção/reprodução, este estudo também observa o dito das fake news nas condições de produção que o sustentam. E, no âmbito das discursividades virais, considera-se a memória enquanto elemento de preservação do real histórico.

\section{Novas demandas para a "máquina discursiva"}

Ao se referir ao empreendimento de uma "máquina discursiva" proposto por Michel Pêcheux, Maldidier afirma que "é pela construção de um dispositivo informático que começa a aventura do discurso" (2017, p. 43). Nossa retomada se dá pela atualização dos elementos constitutivos dessa relação com a entrada em cena das mídias digitais. E, com elas, faz-se a ampliação da capacidade artificial de propagação da informação e da desinformação nas sociedades de classe.

\footnotetext{
${ }^{4}$ Ver Figura 1.

${ }^{5}$ Fundada em $1^{\circ}$ de novembro de 2015, a Lupa é a primeira agência de notícias do Brasil especializada em fact-checking (técnica de checagem jornalística). Integrante da rede mundial de checadores - International Fact-Checking Network (IFCN) -, está hospedada no site da Folha e do UOL, embora não tenha vínculo editorial com essas empresas.

${ }^{6}$ As agências de fact-checking são responsáveis por checar a veracidade de informações veiculadas nas mídias convencionais e digitais. Cabe lembrar que a imagem aqui analisada é considerada de domínio público, sendo impossivel rastrear a sua origem.
} 
Embora os estudos empreendidos por Pêcheux não estejam relacionados à realidade posta pela eclosão da Cultura da Convergência (JENKINS, 2009) ${ }^{7}$, com interações entre as novas e as antigas mídias, ele antecipa em sua proposta de Análise Automática do Discurso questões fundamentais para o entendimento do diálogo entre a tecnologia e os ambientes discursivos contemporâneos. Marandin e Pêcheux, no artigo Informática e Análise do Discurso, afirmam que "a referência à informática em Análise do Discurso não é nem recente nem o resultado de um efeito de moda [...] essa referência à informática corresponde a escolha de duas ordens" (2011, p. 111), uma escolha de política científica e uma escolha metodológica. Trata-se, por esta via, de um trabalho no qual elementos como inteligência artificial, "que visa a simular os mecanismos da inteligência humana" (ibidem, p.112) e algoritmo $^{8}$ despertam o interesse da AD. Trazidos para o contexto atual, esses dois aspectos são fundamentais para o entendimento da indissociabilidade entre tecnologia e real histórico.

Para Pêcheux, “[...] o ponto importante é que esta utilização de instrumentos é diretamente utilizada para autorizar ou, ao contrário, contestar posições ideológicas" (PÊCHEUX, 1975 apud HENRY, 2014, p. 22). Ao desconsiderar aspectos basilares da produção de notícias jornalísticas, as fake news rompem com protocolos mínimos de noticiabilidade, a exemplo da apuração dos fatos e checagem dos dados. A demanda posta por essa configuração comunicativo/discursiva deve ser observada, nesse momento, a partir de aspectos tecnológicos, dentre os quais, apontamos a possibilidade de reprodução da informação em velocidade e escala até então inexistentes, se comparadas às mídias clássicas. Trata-se de pensar:

O que é a carteira de assinantes de um jornal, algo em torno dos 250 mil leitores, como no caso dos maiores diários do Brasil, perto da escala de um Facebook, que tem perto de 2 bilhões de usuários com perfis ativos, quase um terço da humanidade? (BUCCI, 2018, p. 28).

Vê-se, então, que a desproporção entre a capacidade de reprodução da informação e de sentidos, por parte das mídias tradicionais em relação às digitais, é abissal. Um aspecto, cujo alcance e especificidade discursiva precisa ser enfrentado, diz respeito ao engajamento dos usuários/consumidores de fake news à pauta moral e de costumes ligadas à sexualidade e às configurações de gênero. Tal aspecto nos permite estabelecer uma analogia entre os

\footnotetext{
${ }^{7}$ Novo ambiente de mídia com fluxo mais livre de ideias e conteúdos e no qual os consumidores/usuários usam a tecnologias para ter controle sobre o fluxo da mídia e interagir com outros consumidores (JENKINS, 2009).

${ }^{8}$ Algoritmos não são necessariamente softwares: em seu sentido mais amplo, são procedimentos codificados que, com base em cálculos específicos, transformam dados em resultados esperados. Eles desempenham um papel cada vez mais importante na seção das informações consideradas de maior relevância para nós (GILLESPIE, 2014, p. 97).
} 
usuários/consumidores das fake news e os sujeitos pragmáticos, nos termos trazidos por Pêcheux.

Cabe lembrar que não tratamos apenas das necessidades equívocas que os aproximam na história, na língua e nos sujeitos. Consideramos a notícia falsa enquanto materialidade discursiva que se afirma pela repetição, tendo em conta que "há repetições que fazem discurso: é nesse ponto que se conectam a problemática da eficácia ideológica ("um discurso pega quando o retomamos")" (COURTINE; MARANDIN, 2016, p. 46, grifo dos autores). Nessa perspectiva, o movimento de retomada não se dá apenas no compartilhamento viral da notícia falsa, mas no apoio dos algoritmos que não devem ser vistos apenas como códigos com consequências, mas como:

O mais recente mecanismo construído socialmente e institucionalmente gerenciado para convencer o julgamento público: uma nova lógica de conhecimento. A lógica algorítmica depende das escolhas procedimentalizadas de uma máquina, projetada por operadores humanos para autorizar alguma representação de julgamento humano ou desenterrar padrões através de traços sociais coletados (GILLESPIE, 2014, p.167-168).

Nesse movimento de retomada, recorremos a uma rede de memória alusiva à inquisição de sentidos empreendida contra os gêneros não-binários - situados fora do padrão masculino/feminino predominante - nas fake news. Referimo-nos aqui ao que Pêcheux define como "sentidos entrecruzados da memória mítica, da memória social inscrita em práticas" (2015b, p. 44), considerando que as notícias falsas se apropriam do assunto com o intuito de regular/censurar identidades de gênero descoladas dos padrões heteronormativos.

Ao trazermos as fake news para o debate sobre os efeitos da interpelação aos gêneros não-binários, enfatizamos os meios (as práticas técnicas) que possibilitam a circulação de sentidos virais compartilhados e repetidos de maneira espontânea, e artificialmente, em diferentes mídias - redes sociais, blogs, e-mails, etc. De acordo com Pêcheux, o jogo metafórico, enquanto possibilidade de articulação discursiva, permite "uma espécie de repetição vertical, em que a própria memória esburaca-se, perfura-se antes de desdobrar-se em paráfrase" (2015b, p. 47). Entendemos, então, que tal repetição se apoia na paráfrase como representação de identidades de gênero universalmente aceitas e que, portanto, legitimam padrões hegemônicos.

\section{A regulação do gênero}

Estudo realizado pelo Grupo de Pesquisa em Políticas Públicas para o Acesso à Informação (Gpopai), da Universidade de São Paulo (USP), constatou que 12 milhões de 
pessoas compartilharam conteúdos falsos durante o mês de junho de 2018. Foram monitoradas 500 páginas responsáveis pela difusão de fake news, sobre temáticas políticas, LGBTQIA+ e feminismo. Os números da pesquisa dimensionam o alcance da polarização e da desinformação, principalmente se considerado o volume de seguidores dos perfis de compartilhamento.

Em entrevista ao site Manual de Credibilidade, o coordenador do Gpopai, Pablo Ortellado, declarou que "milhões de usuários do Facebook estão polarizados, são vetores de informação, alvos de uma guerra política. E uma das dimensões desta guerra é o compartilhamento, seja para atacar o inimigo ou reforçar a posição do usuário" (ORTELLADO, 2018, s/p) .

$\mathrm{Na}$ tentativa de desidentificação do gênero com configurações não binárias, as notícias falsas operam em sintonia com práticas discursivas que interditam subjetivações e os respectivos saberes que as definem. Em se tratando da especificidade deste trabalho, a análise das Sequências Discursivas (SDs), incluindo o enunciado principal (texto da informação falsa) e o enunciado secundário (comentários sobre o conteúdo original), permite a identificação do que Pêcheux define como objetos paradoxais:

Esses objetos (sob o nome de povo, direito, trabalho, gênero, vida, ciência, natureza, paz, liberdade...) paradoxais funcionam em relações de forças móveis, em mudanças confusas que levam a concordâncias e oposições extremamente instáveis (PÊCHEUX, 2011, p. 115-116).

Tais objetos, nesta análise, vinculam-se a valores morais e religiosos que remetem à regulação do gênero ideal e ao modelo de família que atende às necessidades da sociedade capitalista, conforme podemos demonstrar na análise da SD principal $(\mathrm{SDp})^{10}-$ Haddad diz que Estado decidirá o sexo das crianças e das SD secundárias (SDs) - comentários A, B, C e D:

\footnotetext{
${ }^{9}$ Disponível em: https://www.manualdacredibilidade.com.br/desinformacao. Acesso em 15 de agosto de 2019.

${ }^{10}$ Em setembro de 2018, a informação enunciada na SD principal (SDp) foi checada pela Agência Lupa, além do site Aos Fatos e do projeto Estadão Verifica. A notícia foi considerada falsa. Segundo a Agência Lupa, até as 13h do dia 27 de setembro de 2018, a informação atingiu mais de 10 mil compartilhamentos apenas no Facebook.
} 
Figura 1 - Fernando Haddad. 2018.

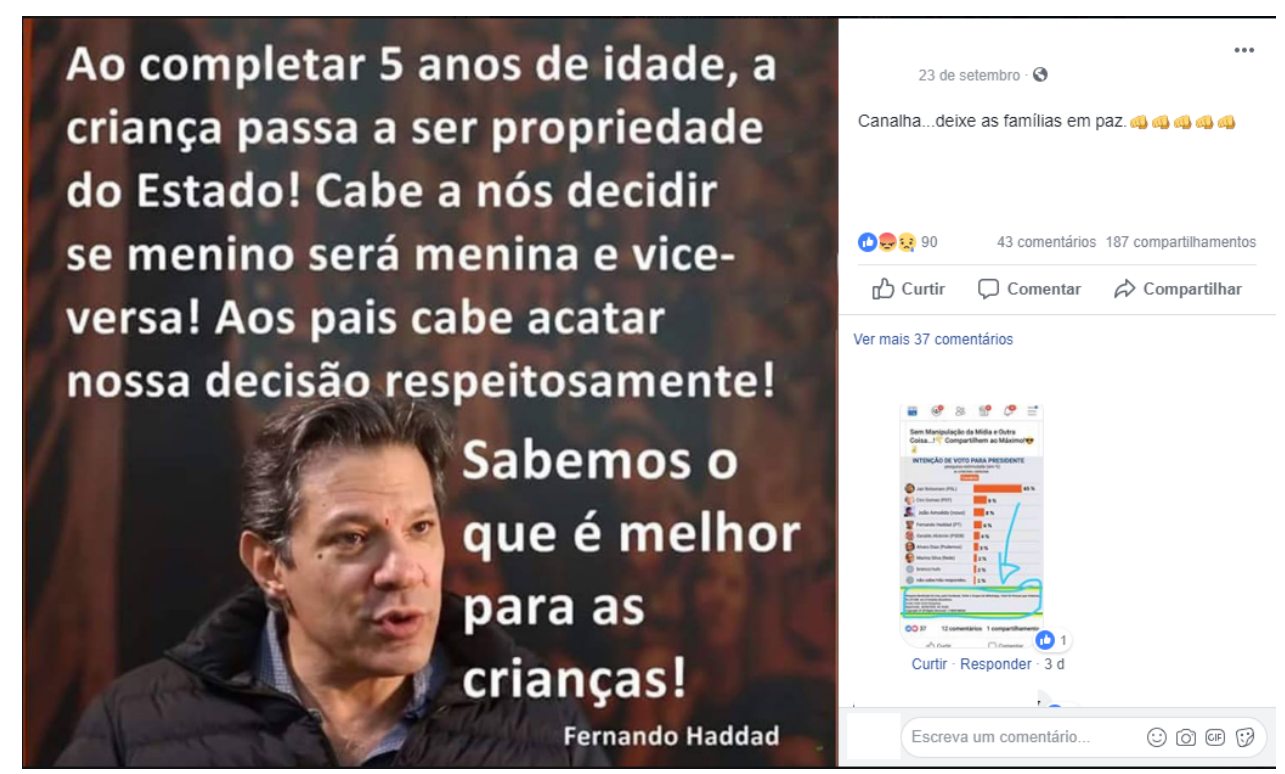

Fonte: BECKER (2018).

SDp: Ao completar 5 anos de idade, a criança passa a ser propriedade do Estado! Cabe a nós decidir se menino será menina e vice-versa! Aos pais cabe acatar nossa decisão respeitosamente! Sabemos o que é melhor para as crianças! Fernando Haddad.

Para além dos aspectos textuais a serem observados mais adiante, o tom sombrio da construção gráfica remete a um desconforto, e a escolha do tamanho da fonte, desproporcional ao espaço, indica algo sufocado, que sai quase que como um grito, o que é reforçado pelo uso do negrito e pelo aumento no tamanho da fonte no segundo parágrafo. Por sua vez, a cor escura da camisa realça o rosto no enquadramento, enquanto a expressão facial e a boca entreaberta indicam que é Haddad quem está falando (o que é reforçado pela assinatura que segue abaixo), remetendo à ilusão da autoria, ao tempo em que sua imagem não olha para os interlocutores.

Com base na SDp, partimos do conceito de família definido pelo Artigo 226 da Constituição Brasileira/1988 para entender a relação estabelecida entre Estado e propriedade privada no enunciado da SDp, uma vez que ao trazer elementos de saber do campo jurídico, evoca-se o texto constitucional: "A família, base da sociedade, tem especial proteção do Estado" (BRASIL, 2016, p. 131). Desse modo, constrói-se uma discursividade que remete à fala de Fernando Haddad para o que seria um direito do Estado, expresso na Carta Magna e, até então, não exercido por outro candidato. 
Ainda no campo constitucional, no capítulo III, o Art. 205, que versa sobre Educação, reitera a educação não apenas como um direito, mas novamente como um "dever do Estado e da família" (BRASIL, 2016, p. 123), em que, na incompetência do primeiro (o Estado), a família assumiria tal atribuição (e vice-versa), ou em considerando as suas especificidades, os dois assumiram corresponsabilidades, simultaneamente. Soma-se aos elementos de saber do direito a referência ao domínio do biológico nos processos de desenvolvimento humano.

Na SDp, situa-se a idade de 5 anos como aquela em que o Estado tomaria para si a prerrogativa de intervir em questões de gênero e de sexualidade da criança. Sabemos que, no estágio do desenvolvimento humano, a fase do pré-operatório (dos 2 aos 7 anos) é descrita por Jean Piaget pela entrada da função simbólica e da linguagem, o que corresponde a aquisições cognitivas, sociais e emocionais (PIAGET, 1996). Todavia, o enunciador evoca com um discurso que já está funcionando em outro lugar, na ciência, no Direito, na Biologia, na Educação. Pelo interdiscurso, então, é possível recuperar a memória desses saberes, que parecem legitimar a falsidade da notícia.

A utilização de determinados verbos, por sua vez, reforça os sentidos na cena enunciativa, em que "completar" e "passar" referem-se às crianças, enquanto "decidir" e “saber" se voltam para o sujeito da enunciação. Por sua vez, "decidir" implica também possibilidades, afinal quem não tem possibilidades não faz escolha, mas quais eram as possibilidades de escolha? Na discussão sobre posse e guarda das crianças, a expressão "aos pais cabe acatar" traz a noção de que a criança passa a ser propriedade do Estado, enquanto aos pais cabe a posição passiva/pacífica de apenas acatar as determinações estatais. Esse movimento materializa uma funcionalidade do discurso dominante, explicitando quem manda e quem obedece, materializando a voz do dominante.

Ao comprometer um determinado leitor pela suposta identificação, "sabemos" pressupõe um saber (quem sabe o quê), e o efeito de transitoriedade é reforçado pelo uso do "se", que passa a ser outra coisa. Polêmicas à parte, a opção pela exclamação pode apontar para o que seria uma escrita feminina, que apela para um caráter emocional ou de ênfase, de espanto. Por sua vez, trazer o pronome pessoal de primeira pessoa do plural ("nossa"), simulando não se tratar de uma fala individualizada/personalizada, permite considerar que o sujeito da enunciação representa várias vozes, o Estado e tudo o que Fernando Haddad representa: a esquerda política. Reforçando uma suposta passividade, enquanto se pretende provar o contrário, evoca-se o respeito, como sentido viral, produzido por dizeres respeitosamente falsos. 


\section{Na ilusão de uma época, a base religiosa na origem do gênero universal}

A circularidade de sentidos, constitutiva das mentiras propagadas em rede, aparece ancorada nos comentários associados aos enunciados principais e que acirram a polarização, direcionando para formas ideológicas da submissão dos indivíduos:

Essa divisão nas formas de submissão é decisiva para meu início: ela se deixa apresentar esquematicamente por meio de uma série de oposições no que diz respeito às diferenças práticas na relação dos sujeitos com seu corpo, sua língua, seu pensamento [...] Observamos também o costume à obediência e ao adestramento; invocação religiosa como comportamento ritualizado (com as práticas de doutrinação, da censura e da confissão) (PÊCHEUX, 2015b, p. 109).

Divulgada em diferentes mídias, e posteriormente incorporada às notícias falsas, a polarização culmina com a entrada de uma suposta "ideologia de gênero" na pauta nacional, o que pode ser constatado em dois momentos cruciais. O primeiro relaciona-se ao cenário político marcado pela ascensão da bancada evangélica no Congresso Nacional, tendo seu ápice nas eleições de 2018. O segundo acompanha a eclosão das ações do Movimento/Projeto Escola Sem Partido, a partir de sua proposição em 2014.

E, nesse aspecto, é importante entender a maneira como as fake news exercem um controle social nas subjetivações de gênero e na circulação dos sentidos virais sobre o tema. Observamos o empenho de determinados grupos em retirar das escolas brasileiras temas relativos à sexualidade e à diversidade - igualdade e equidade - de gênero, a exemplo do que é possível observar nas Sequências Discursivas extraídas dos comentários.

SDs1 [Comentário A] - Canalha..., deixe as famílias em paz.

O uso da expressão "Canalha", em referência ao então candidato Fernando Haddad, decorre de uma conclusão a partir do que é apresentado em SDp, situando-se, portanto, como efeito de sentido, produzido pela "certeza" de que Haddad é um canalha, por ter dito o que (não!) disse. Para além dessa conclusão, as reticências apontam para um espaço em aberto no qual muitos outros adjetivos pejorativos podem ser evocados, indicando o que não está dito, e, nos termos de Orlandi (2007), silenciado.

Por sua vez, no emprego do imperativo "deixe as famílias em paz", além da não identificação de quais famílias são enunciadas, também não são definidos os sentidos que estão sendo mobilizados para a paz. Não se trata, no entanto, de "nossas famílias"/SDp, mas de realçar "as" famílias, sem abrir margem para as exceções à suposta homogeneidade que se tenta produzir nos interlocutores, ao se referir de modo imperativo a "Haddad", em específico, pela construção: [Haddad] Canalha [...], deixe as famílias em paz." 
Entendemos haver um processo de identificação do sujeito da enunciação com o sujeito do discurso e com o "auditório" das notícias falsas: "a multidão, o "povo", no sentido cristão" (PÊCHEUX, 2014, p.201). Aqui há também o funcionamento de um "nós" ("Deixe as nossas famílias em paz") que se opõe ao "nós” da SDp (“cabe a nós decidir ser menino ou menina").

Figura 2 - Comentário B.

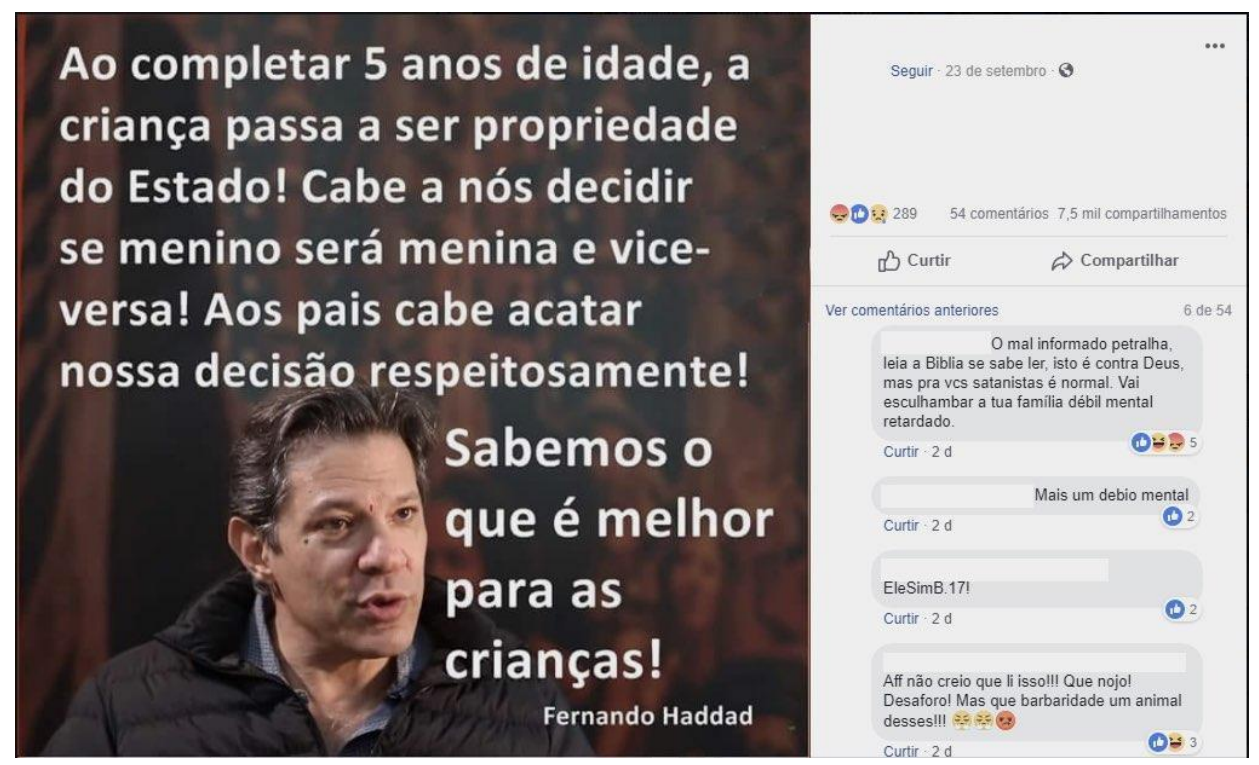

Fonte: BECKER (2018).

SDs2 [Comentário B] - O mal informado petralha. Leia a Bíblia se sabe ler. Isto é contra Deus. Mas pra vocês satanistas é normal. Vai esculhambar a tua família débil mental retardado.

Para Pêcheux, o interdiscurso é algo que fala sempre "antes, em outro lugar e independentemente" (2014, p. 149). A partir desse entendimento, consideramos que "Petralha" é apresentado como um modo de adjetivação que remete ao campo político comunista, sendo tal acionamento produzido por uma memória que traz um sentido pejorativo da militância de esquerda no Brasil.

Por sua vez, "satanistas" evoca sentidos de ordem religiosa. Em "Mas pra vocês satanistas é normal", retoma-se o par normal/anormal, marcado pela adversativa ("mas") afirmando a normalidade da notícia falsa, para Haddad e seus eleitores, adjetivados como "satanistas" em razão do seu (suposto) posicionamento quanto ao gênero. Como contraponto ao satanismo, o imperativo "Leia a Bíblia" recupera as bases do Cristianismo, enquanto parâmetro de verdade assumido pelo sujeito do discurso dominante. A partir do pressuposto 
cristão, na dualidade que se encerra na relação entre Deus (forma-sujeito do discurso religioso judaico-cristão) e Satanás (o Seu opositor), conclui-se que a proposta de Haddad ("Isto") "é contra Deus", numa construção na qual "isto" sintetiza, enquanto eufemismo, tudo o que supostamente foi dito por Haddad.

Para além do caráter imperativo, em "Vai esculhambar a tua família" o uso do "tu", ao tempo em que traz certa formalidade (em distinção ao você, por exemplo), pelo desvio na concordância com o verbo (vai) ao invés de "vais", aponta para uma escrita que se torna informal/coloquial e que particulariza na família de Haddad um modelo de família que se opõe à Bíblia e a Deus. Por seu turno, as expressões "débil mental" e "retardado" põem em perspectiva o discurso biomédico/psiquiátrico, num mecanismo pejorativo de diagnóstico médico. Nesse entrecruzamento discursivo, são identificados pelo menos três discursos alinhados, o político, o religioso e o biomédico/psiquiátrico, produzindo efeitos de sentido na circulação da notícia falsa, em que os diferentes modelos de família (do Estado, da religião cristã e da saúde) são postos em relação, para, pelo ataque à "ideologia de gênero", mobilizar o eleitorado brasileiro contra o candidato petista Fernando Haddad. 
Figura 3 - Comentário C.

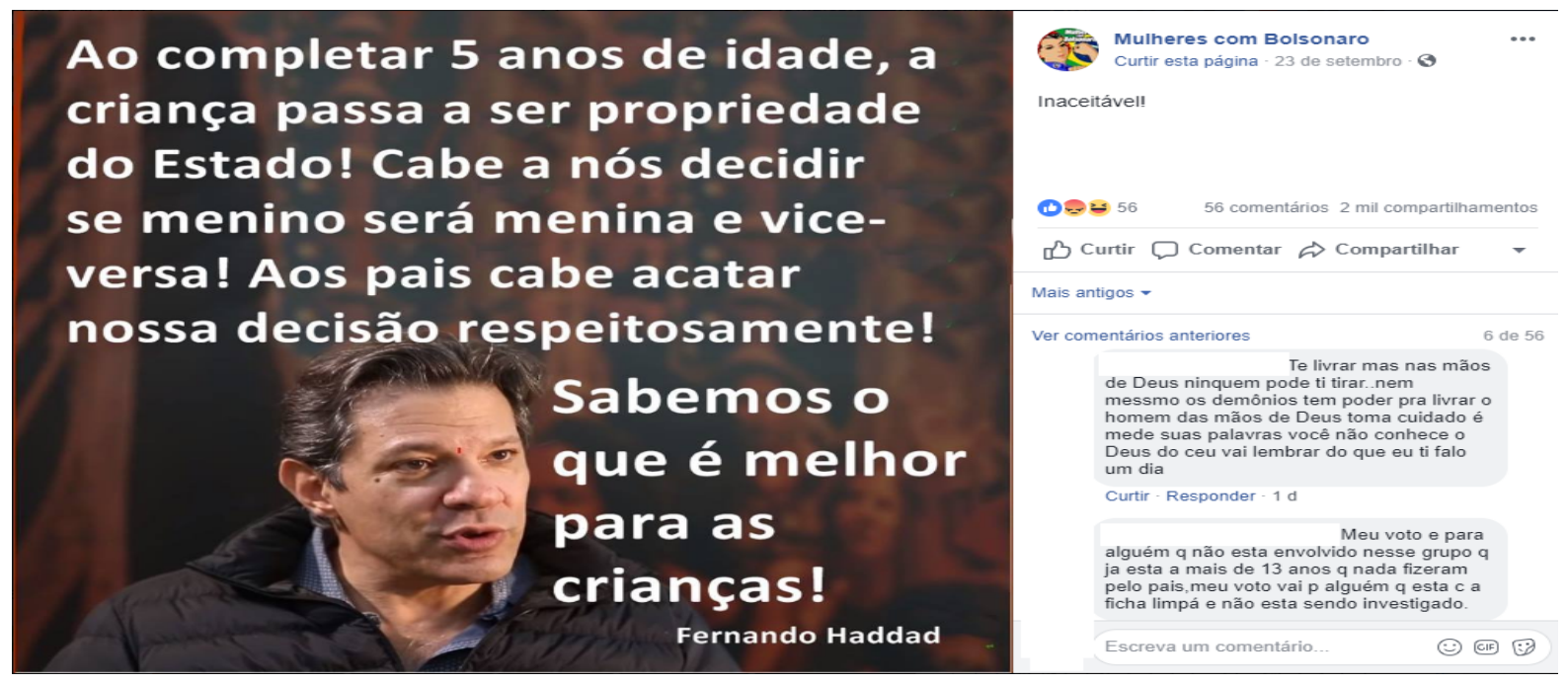

Fonte: BECKER (2018).

SDs3 [Comentário C] - Te livrar mas nas mãos de Deus ninguém pode te tirar. Nem mesmo os demônios tem poder pra livrar o homem das mãos de Deus. Toma cuidado e mede suas palavras. Você não conhece Deus do céu. Vai lembrar do que te falo um dia.

O uso do verbo livrar (pressupondo que Haddad esteja preso) traz para o campo religioso a possibilidade da libertação, mas curiosamente aponta para um deslize em que a prisão do interlocutor (e não a sua liberdade) está nas "mãos de Deus", enquanto um destino inevitável aos que se opõem à vontade divina, conforme a verdade expressa na Bíblia: "E conhecereis a verdade e a verdade vos libertará" (João 18:38). Todavia, o discurso religioso reforça o medo ("toma cuidado, ninguém pode te livrar, nem mesmo os demônios tem poder pra livrar o homem, mede suas palavras, vai lembrar do que te falo um dia") enquanto efeito que se amplia para os interlocutores (eleitores) simpatizantes do então candidato, o que, por extensão, permite colocar em relação o bem e o mal, Deus e Satanás [Haddad]. O não dito que se opõe a Haddad nessa relação é, portanto, a posição-sujeito com a qual se identifica o sujeito da enunciação.

Por efeito metafórico, as "mãos de Deus" representam um lugar de castigo e de prisão, reforçando o sentido de medo de um Deus ameaçador, do qual não se pode escapar. Todavia, "ninguém" não significa todas as pessoas, mas, pelo funcionamento da restrição, remete aos que se identificam com a formação discursiva religiosa em questão. Em SDs2 e SDs3, há um "eu" que fala em nome de Deus, assumindo a função de "porta-voz", o que "permite identificar por quem a demanda pública é feita" (CONEIN, 2016, p. 93). Na referida SD, o 
sujeito universal do discurso religioso judaico-cristão (Deus) está representado no sujeito da enunciação.

Observa-se também que o enunciado da SDp mobiliza uma memória do comunismo naturalizada nas sociedades de classe. Embora o candidato Fernando Haddad não tenha aparente relação com o comunismo, a campanha eleitoral foi pautada pela polarização entre partidos de "esquerda" x "direita", naturalizando a falsa universalidade da esquerda política associada aos comunistas.

Retomamos Courtine, com o propósito de situar as condições de produção na qual a memória discursiva está inscrita, atravessando a complexidade da maneira como o comunismo entra no campo de atualidades políticas e religiosas trazidas pela fake news de gênero. É necessário entender que a "noção de memória discursiva diz respeito à existência histórica do enunciado no interior das práticas discursivas regradas por aparelhos ideológicos" (2014, p. 106).

Ainda conforme o referido autor, o comunismo:

\begin{abstract}
Inscreve-se no registro metafórico do contágio mortal, dando assim o tom dos julgamentos que, mais tarde, serão proferidos, porém, com atenuações notáveis depois do Vaticano II. Socialismo e comunismo aparecem assim como princípios contra a natureza: o direito à propriedade privada é de fato sancionado pelo direito natural, assim como a hierarquização das classes sociais (COURTINE, 2014, p. 134, grifos do autor).
\end{abstract}

Para Courtine, a resistência essencial inscreve-se no plano teórico, impossibilitando a “conciliação doutrinal" com o materialismo histórico, considerando que o comunismo é "sistema de pensamento negador de Deus e perseguidor da Igreja", segundo termos de Paulo VI (2014, p. 134). Em se tratando do Partido Comunista Brasileiro, Mariani, estabelece um quadro histórico na referenciação e no lugar imaginário por ele ocupado, considerando enunciados jornalísticos, pois durante décadas, "o comunismo foi representado como uma ameaça aos valores estabelecidos [...]. As palavras direita e esquerda caracterizavam, e ainda caracterizam, distintas concepções sociais e econômicas, resultantes de modelos políticos diferentes" (1998, p. 20, grifo da autora).

Por sua vez, a análise da SDp possibilita entender também os efeitos discursivos de uma informação que, mesmo comprovadamente falsa, após trabalho de checagem, ultrapassou mais de 150 mil amplificações, algumas delas amplificações fabricadas ${ }^{11}$, que legitimam posições-sujeito heteronormativas. Cabe lembrar que a amplificação da SDp prosseguiu

\footnotetext{
${ }^{11}$ Amplificação fabricada (manufactured amplification) acontece quando o alcance ou a difusão da informação são impulsionados por meios artificiais. Isso inclui manipulação humana ou automatizada de mecanismos de busca.
} 
mesmo após a decisão 0601437-91.2018.6.00.0000 ${ }^{12}$, proferida pelo Colegiado do Tribunal Superior Eleitoral (TSE) contra o Facebook Serviços Online do Brasil Ltda. Tal decisão obrigou a retirada do ar da página "Cacilda", responsável por mais de cem mil compartilhamentos da notícia falsa.

Ainda na SDp, o uso da imagem do então candidato Fernando Haddad conferiu sentido de autoria e de autoridade ao dito, uma vez que não se tratava de qualquer pessoa enunciando, mas de uma circulação de fala pública. É preciso considerar, portanto, que

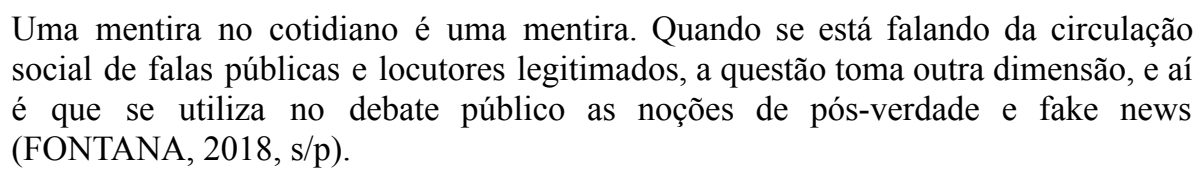

Ao tratar da imagem enquanto operador de memória social, "a imagem funciona como um marcador de realidade, e principalmente: ela pode também conservar a força das relações sociais (e fará então impressão sobre o espectador)" (DAVALLON, 2015, p. 25). Em se tratando da desinformação deliberada, estabelecer pequenos vínculos com uma aparente realidade representa um aumento significativo da possibilidade de adesão à notícia falsa.

A imagem teria, assim, capacidade para integrar os elementos que a compõem em uma totalidade. É porque compreenderíamos o sentido global antes de reconhecer a significação dos elementos (DAVALLON, 2015, p. 28).

Essa capacidade imagética é fundamental para o acionamento dos sentidos virais em fake news, visto que implicaria uma maior rapidez do acionamento da memória, antecipando posições instantâneas. A observação do funcionamento das fake news nos leva, então, a estabelecer vinculações constitutivas entre as coisas a saber que marcam o discurso de gênero e a informação manipulada. Tal constatação corrobora com o vínculo dos dizeres das notícias falsas aos sentidos mobilizados nas formações discursivas político-religiosas conservadoras. Como vemos nos comentários que seguem, é estabelecido um alto grau de antagonismo entre o povo de Deus, de um lado, e a canalhada, a esculhambação, o satanista, a debilidade mental, o retardo, em sentido oposto.

SDs1 - Comentário A: Canalha..., deixe as famílias em paz.

SDs2 - Comentário B: O mal informado petralha. Leia a Bíblia se sabe ler. Isto é contra Deus, mas pra você satanista, é normal. Vai esculhambar a tua família debil mental retardado.

\footnotetext{
${ }^{12}$ Trata-se de representação, com pedido liminar e de direito de resposta, ajuizada pela Coligação O Povo Feliz de Novo e por seu candidato ao cargo de presidente da República, Fernando Haddad, contra Facebook Serviços Online do Brasil Ltda. 
SDs3 - Comentário C: Te livrar mas nas mãos de Deus ninguém.

Em SDs1, especificamente, o uso de reticências indica/funciona como uma espécie de guarda-chuva para tudo aquilo que é considerado negativo e que ameaça o sentido de família, ideologicamente estabilizado. Para Pêcheux, “os objetos ideológicos são sempre fornecidos ao mesmo tempo em que a maneira de se servir deles, seu sentido, isto é, sua orientação, ou seja, os interesses de classe aos quais eles servem" (2014, p. 132, grifos do autor), o que reforça uma rede de significações estabelecida a partir da adesão ou oposição dos usuários (sujeitos pragmáticos) ao conteúdo replicado.

Por sua vez, a figura de Deus é recorrente nos comentários da SDp (SDs1, SDs2 e SDs3), demonstrando a influência da Formação Discursiva (FD) religiosa. Em se tratando da submissão às práticas religiosas, Maldidier lembra que:

Comentando Spinoza, Michel Pêcheux diz belamente: "Deus não tem nenhum estilo próprio: pela boca dos profetas ele fala de modo diferente da mesma coisa; ele pode também designar coisas diferentes através das mesmas palavras” (2017, p. 72, grifos da autora).

A afirmação é corroborada por Courtine e Marandin, para quem uma FD não é "uma só linguagem para todos", tampouco "cada uma com sua linguagem", mas "as linguagens em um mesmo", considerando que o fechamento de uma FD "não consiste em um limite traçado de uma vez por todas que separa um interior e um exterior, mas se inscreve entre diversas FDs como uma fronteira que se desloca em função das questões da luta ideológica" (2016, p. 39, grifos dos autores).

Nas mentiras programadas, as recorrentes tentativas de apagamento impostas às determinações de gênero situadas fora do escopo heteronormativo (masculino-feminino) relacionam-se com a desvinculação entre prática social e ideia dominante de um gênero dominante. A trajetória discursiva, que acompanha a entrada do termo "ideologia de gênero" no debate nacional, impulsionando a máquina de produção dos conteúdos falsificados, mostra a pertinência e a atualidade dessa análise. Na medida em que tangencia identidades e subjetivações, o discurso político-religioso impõe uma noção de gênero e a regulação da sexualidade com base em padrões androcêntricos, conforme demonstraremos a seguir.

A análise da base sócio-histórica que possibilitou a inserção do referido tema no debate nacional é relevante para entender os aspectos que incidem nos processos discursivos e que se ocupam das diferentes dimensões de gênero, provocando, no dizer de Pêcheux, “nuvens de fumaça, cujas camadas, atualmente, não param de se estender" (2014, p. 276). 
Trazidas para o campo das identificações de gênero (homem, mulher, ambos ou nenhum), as "nuvens de fumaça" comprometem a permanência de visibilidades histórico-sociais e de subjetivação, colocando o gênero como alvo de determinados processos discursivos. Sobre os caminhos pela legitimidade do diferente em meio à homogeneização de padrões preestabelecidos, convém considerar que

No jogo especular das formações imaginárias, das projeções antecipadas que demandam diversos modos de estar no mundo, ser reconhecido e se reconhecer em relação ao funcionamento social e histórico das masculinidades e das feminilidades, em toda a sua dimensão contraditória e equívoca, faz parte do processo de constituição do sujeito do discurso (FONTANA, 2017, p. 65).

Nessa perspectiva, a enunciação do gênero em fake news não se dá de maneira apartada do real da língua e do real histórico, tendo em conta que a reprodução do gênero em notícias falsas articula-se nas práticas sociais, políticas e religiosas. Ela surge num movimento discursivamente articulado e engendrado em processos de silenciamento (ORLANDI, 2007).

$\mathrm{Na}$ crítica aos idealistas alemães, que se baseavam na separação entre a história e a base real da vida comum, Marx e Engels chamam de ilusão de cada época histórica, para quem a concepção verdadeiramente religiosa "pressupõe o homem religioso como o homem primitivo do qual parte toda a história e, em sua imaginação, põe a produção religiosa de fantasias no lugar da produção real dos meios de vida e da própria vida" (2007, p. 44). Em concordância com os referidos autores, é preciso entender a maneira pela qual a desarticulação entre história e práxis social implica distorções e regulações morais. E, consequentemente, gera fantasias e deformações, a exemplo da inserção da expressão "ideologia de gênero" num amplo contexto, que vai da reformulação das bases da educação no Brasil à tentativa de regulação moral via fake news.

A origem da referida expressão é descrita na reportagem "Saiba como surgiu o termo 'ideologia de gênero"”, veiculada no jornal Folha de S. Paulo, em 23 de outubro de 2018 (SALDAÑA, 2018). A matéria publicada na editoria de Cotidiano faz referência ao artigo ““Ideologia de gênero': a gênese de uma categoria política reacionária - ou: a promoção dos direitos humanos se tornou uma 'ameaça à família natural?'”, no qual o pesquisador da Universidade de Brasília (UnB) Rogério Diniz Junqueira faz referência ao termo, citado pela primeira vez em 1998, em documento eclesiástico, em uma nota da Conferência Episcopal do Peru, intitulada "A ideologia de gênero: seus perigos e alcances".

Explicitar o viés religioso/conservador, que acompanha a produção das fake news, é relevante para demonstrar as relações de sentido estabelecidas entre os enunciados e o 
acirramento do debate sobre as identificações de gênero. Citado inicialmente em 1994, durante a Conferência de População do Cairo, o conceito de gênero ganhou espaço em diretrizes religiosas. Em 2000, a Cúria Romana publicou o documento "Família, Matrimônio e União de Fato". Posteriormente, o Vaticano prosseguiu na inquisição contra o gênero, cujo ápice, em 2008, foi ratificado pelo então Papa Bento XVI, que descreveu gênero como "algo que contrariaria e desprezaria a natureza, e poderia levá-la à autodestruição”. Esse não foi o único episódio em que o referido pontífice se referiu ao assunto. Em dezembro de 2012, retomou a crítica às teorias de gênero durante o pronunciamento de Natal.

A observação do modo como o Vaticano enunciou o assunto corrobora com a concepção de Marx e Engels, na qual a ilusão religiosa pode se configurar na força motriz da história. Conforme os referidos autores, essa configuração de força "põe a produção religiosa de fantasias no lugar da produção real dos meios de vida e da própria vida" (2007, p. 44). Dessa maneira, a formação discursiva religiosa, com potencial de reverberação em hiperescala, está a serviço da reprodução dos sentidos orientados pela ultradireita nacionalista. Tais sentidos são direcionados para balizar padrões morais reducionistas, notadamente aqueles que dizem respeito à complexidade de gêneros, que extrapolam as fronteiras binárias de masculino x feminino.

\section{Gênero mobiliza sentidos de fé à direita}

Como todo discurso é sempre produzido a partir das condições de produção dadas (PÊCHEUX, 2014), destacamos que, no Brasil, o posicionamento da Igreja Católica Apostólica Romana, também em relação ao debate de gênero, expande-se para as denominações (neo)pentencostais. Dados do Departamento Intersindical de Assessoria Parlamentar (DIAP) confirmam que o avanço da bancada evangélica no Congresso aumentou e que o número de parlamentares subiu de 78 para 91 nas eleições 2018.

Em 2015, segundo o DIAP, eleitores evangélicos, que correspondem a 30\% da população, passaram a ser representados no Congresso Nacional por 17\% dos deputados e 4\% dos senadores. Tal representação nos remete novamente à concepção de Marx e Engels (2007) sobre a maneira como o curso da história articula e transforma as ideias da classe dominante em ideias dominantes que "não são nada mais do que a expressão ideal das relações materiais dominantes, são as relações materiais dominantes apreendidas como ideais" (MARX; ENGELS, 2007, p. 47), em um movimento no qual a política passa a representar os ideais de grupos religiosos específicos e alinhados ao pensamento da classe social que detém o poder, o que constitui a base material das condições de produção dos discursos dominantes. 
O estado das condições de produção tem respaldo numa estrutura definida que incide "nos processos de produção do discurso a partir da língua", o que indica que as condições fixadas correspondem a um conjunto de "discursos sucessíveis de serem engendrados nessas condições, se manifesta invariantes semântico-retóricas estáveis" (PÊCHEUX, 2014, p. 74). Para o referido autor, é importante que sequências discursivas fechadas sejam referidas em relação a outros discursos possíveis, "a partir de um estado definido das condições de produção" (ibidem, p. 78), tendo em perspectiva que

\footnotetext{
Num estado dado das condições de produção de um discurso, os elementos que constituem esse estado não são simplesmente justapostos, mas mantêm entre si relações suscetíveis de variar segundo a natureza dos elementos colocados em jogo (ibidem, p. 85).
}

Identifica-se o deslocamento do dominante na produção de conteúdos ligados à regulação da moral e dos costumes. Por essa razão, o alinhamento das fake news de gênero à moral e às orientações de base religiosas católica e (neo)petencostais reforça as diretrizes políticas, que buscam circunscrever o trânsito de diferentes gêneros aos esquemas normativos naturalizados em diferentes instâncias (família, religião e política).

Ao situar a política como um campo de sedução com horizontes ampliados pelo desenvolvimento das novas mídias, Conein et al. afirmam que "governar é aparecer. O Estado teria se tornado um espetáculo; a política, um show televisivo; a imagem dos homens públicos, energia essencial da convicção; e seu corpo, uma peça indispensável da arte de governar" (CONEIN, 2016, p. 117). O ato de governar foi e permanece sendo o saber mostrar-se. A encenação política do corpo não é mais ilusória hoje do que aquela da qual Versalhes constituía o faustoso teatro. A expressão Estado-espetáculo convém, aliás, melhor ao século do Luís XIV do que ao nosso, que é, antes, aquele do indivíduo-espetáculo (CONEIN, 2016).

Em se tratando das notícias falsas e de sua propagação em redes on-line, a política do espetáculo assume uma potência até então inédita, inserindo entre os principais elementos da cena a desconstrução da possibilidade do entendimento do gênero como algo deslocado de normas universais. Para Conein (2016), as mutações decorrentes das transformações nas tecnologias de comunicação de massa evocam mutações complexas no espetáculo político.

$\mathrm{O}$ alinhamento das fake news de gênero à moral e às orientações de base religiosa católica e (neo)pentencostais reforça as diretrizes políticas, que buscam circunscrever o trânsito de diferentes gêneros aos esquemas normativos naturalizados em diferentes instâncias (família, religião e política). De acordo com Marx e Engels (2007), as novas classes 
dominantes têm o poder de impor ideias e validá-las como algo de interesse coletivo e com desdobramentos na vida cotidiana das pessoas, mesmo que tais "ideias dominantes" não tenham ressonância mínima com a práxis de cada época, a exemplo das questões relativas às reconfigurações de gênero.

Nessa perspectiva, a influência do discurso religioso, associado ao político, é determinante para a entrada da inquisição do gênero não-binário nas sociedades de classe. Para Paveau, a noção de classe social é imprescindível no trabalho com o gênero, tendo em conta que os estudos relacionados ao gênero inserem-se num "lugar possível para a repolitização da teoria do discurso, efetivamente, eles poderiam ser qualificados como materialistas, no sentido histórico" (2019, p. 291). Daí, "trabalhar com o gênero supõe levar em conta o corpo em sua materialidade e, mais amplamente, considerar, na análise dos discursos, as condições de vida materiais dos sujeitos" (PAVEAU, 2019, p. 291, grifo da autora).

A busca pela perpetuação de um gênero como hegemônico é responsável pela consolidação da cena discursiva na qual as notícias falsas operam no reforço ao dominante. Recorremos a Corten (1999), para ressaltar o modo como a encenação do gênero proibido se materializa nas notícias falsas, naturalizando uma suposta transparência própria da teatralização, que mobiliza a intencionalidade da regulação de gênero.

É a cena onde os elementos que perpassam a sociedade são vistos como forças e vistos como forças políticas. Diremos pois que o político é a realidade dessas forças tais como essas se destacam de maneira mais ou menos precisa à vista de todos [...]. É o discurso em circulação que constrói a montagem e delimita o fechamento da cena (CORTEN, 1999, p. 37, grifo do autor).

Diante da ficção constitutiva que compõe a cena das notícias falsas, destacamos o processo de invisibilidade e reforço à política de silenciamento, que, conforme Orlandi, "se define pelo fato de que ao dizer algo apagamos necessariamente outros sentidos possíveis, mas indesejáveis em uma situação discursiva dada" (2007, p. 73). Há que se considerar ainda não apenas onde reside a ilusão da transparência de uma "ideia dominante" que se apresenta como arauto da "isenção ideológica", mas também que

Em relação aos processos de individuação pelo Estado e pelas relações de poder e dominação que configuram uma formação social, as identificações de gênero trabalham os processos imaginários de reconhecimento/desconhecimento que constituem os sujeitos nas suas relações sociais (FONTANA, 2017, p. 65).

Para a referida autora, 
É nessa relação com a alteridade que se instauram as lutas por reconhecimento de outras formas de existência histórica, produzidas por processos de subjetivação nos quais identificações de gênero e sexualidade participam tanto para a reprodução de normas quanto para a sua ruptura e deslocamento (ibidem, p. 65).

Desse modo, os processos discursivos que circulam a partir de uma "ideia dominante" buscam, então, legitimar um conjunto de práticas contrárias ao processo de transformação social pautada na emancipação humana. Assim, ao evocar o gênero hegemônico as fake news dão sustentação ao que já está posto e institucionalizado pela Igreja e pelo campo político, impedindo a construção do reconhecimento das subjetividades e o conhecimento próprio da práxis social.

\section{Considerações finais}

Os sentidos virais têm por base as retomadas discursivas, estabelecidas num jogo simbólico de adesão ao dito a partir de um já-lá. Metaforicamente, entendemos que a condição para inoculação do viral nos sentidos é sua inscrição em formações ideológicas e discursivas dadas. Consideramos que é pela via da repetição/compartilhamento que o campo ideológico se cristaliza num jogo de polarização (o bem e o mal) e paráfrase em que a adesão ao dito, autorizado por uma rede de memória, se processa de maneira instantânea e se reproduz em novos e sucessivos compartilhamentos. Nessa perspectiva, a desinformação premeditada nas fake news, cuja reprodução em larga escala é viabilizada pelo avanço tecnológico, pauta a tentativa de estabilização dos costumes, da moral e do gênero na sociedade contemporânea.

$\mathrm{Na}$ medida em que propagam sentidos circunscritos aos campos político e religioso, tenta-se restringir modos do dizer sobre gêneros outros. Na analogia feita com o fogo inquisitivo, referente ao gênero não-binário, somos movidos pelo que diz Pêcheux (2014), ao tratar da importância do posicionamento crítico, face aos espaços que precisam ser analisados e ocupados. Nas mentiras programadas, as recorrentes tentativas de apagamento, impostas às determinações de gênero situadas fora do escopo heteronormativo (masculino-feminino), relacionam-se à desvinculação entre prática social e ideia dominante de um gênero dominante.

Por sua vez, a trajetória discursiva, que acompanha a entrada do termo "ideologia de gênero" no debate nacional, impulsionando a máquina de produção dos conteúdos falsificados, mostra a pertinência e a atualidade dessa análise. Enquanto tangencia identidades e subjetivações, o discurso político-religioso capitalista impõe uma noção de gênero e a regulação da sexualidade com base em padrões androcêntricos. Desse modo, ratificamos o 
vínculo constitutivo entre o discurso das fakes news, a fé e a política no empreendimento da manipulação dos sentidos virais que regulam o gênero do capital.

\section{Referências}

BECKER, Clara. \#Verificamos: vetada pelo TSE, declaração falsa atribuída a Haddad segue 'viva' nas redes sociais. Agência Lupa, Rio de Janeiro, 27 set. 2018. Disponível em: https://piaui.folha.uol.com.br/lupa/2018/09/27/verificamos-haddad-criancas/. Acesso em: 3 nov. 2020.

BRASIL. Constituição da República Federativa do Brasil [1988]. Brasília/DF: Senado Federal, 2016.

BUCCI, Eugênio. Pós-política e corrosão da verdade. Revista USP, São Paulo, n. 116, p. 19-30, mai. 2018.

CONEIN, Bernard. Descrever um acontecimento político. In. CONEIN, Bernard et al. (org.). Materialidades discursivas. Campinas/SP: Editora da Unicamp, 2016.

CORTEN, André. Discurso e representação do político. In: INDURSKY, Freda; FERREIRA, Maria Cristina Leandro. (org.). Os múltiplos territórios da Análise do Discurso. Porto Alegre: Editora Sagra Luzzatto, 1999.

COURTINE, Jean-Jacques; MARANDIN, Jean-Marie. Que objeto para a Análise de Discurso? In: CONEIN, Bernard et al. (org.). Materialidades Discursivas. Campinas/SP: Editora da Unicamp, 2016.

COURTINE, Jean-Jacques. Análise do discurso político: o discurso comunista endereçado aos cristãos. São Paulo: EdUFSCar, 2014.

DAVALLON, Jean. A imagem, uma arte de memória. In: ACHARD, Pierre et al. (org.). Papel da memória. Tradução de José Horta Nunes. Campinas/SP: Pontes, 2015.

FONTANA, Mónica Graciela. Zoppi. "Lugar de fala": enunciação, subjetivação, resistência. Conexão Letras, Porto Alegre, v. 12, n. 18, 2017. Disponível em: https://seer.ufrgs.br/conexaoletras/article/view/79457/46458. Acesso em: 20 abr. 2019.

FONTANA, Mónica Graciela Zoppi. Mulheres em discurso: linguagem, política e verdade. Entrevista cedida ao Programa Miscelâneas. PNAIC UFSCar, São Paulo, 31 out. 2018. Disponível em: https://www.youtube.com/watch? $\mathrm{v}=$ hen2n3dCCXc\&feature=youtu.be. Acesso em: 20 mai. 2019.

GILLESPIE, Tarleton. The relevance of algorithms. In: GILLESPIE, Tarleton; BOCZKOWSKI, Pablo J.; FOOT, Kirsten A. (org.). Media technologies: essay on communication, materiality, and society. Cambridge: MIT Press, 2014.

HENRY, Paul. Os fundamentos teóricos da "Análise Automática do Discurso", de Michel Pêcheux (1969). In: GADET, F. e HAK, T. (orgs.). Por uma Análise Automática do Discurso: uma introdução à obra de Michel Pêcheux. Trad. Bathânia S. Mariani et al. 5. ed. Campinas/ SP: Editora da Unicamp, p. 11-38, 2014.

JENKINS, Henry. Cultura da convergência. Tradução de Susana Alexandria. São Paulo: Aleph, 2009.

MALDIDIER, Denise. A inquietação do discurso: (re)ler Michel Pêcheux hoje. Campinas/SP: Pontes, 2017.

MARANDIN, Jean-Marie; PÊCHEUX, Michel. Informática e Análise do Discurso. In: MARIANI, Bethania. $O P C B$ e a imprensa: os comunistas no imaginário dos jornais (1922-1989). Rio de Janeiro: Revan, 1998.

MARX, Karl; ENGELS, Friedrich. A ideologia alemã. São Paulo: Boitempo, 2007.

ORLANDI, Eni Puccinelli. As formas do silêncio: no movimento dos sentidos. Campinas: Editora Unicamp, 2007. 
ORTELLADO, Pablo. [S/i]. Entrevista cedida a Manual da Credibilidade. Manual da Credibilidade, São Paulo, 2018. Disponível em: https://www.manualdacredibilidade.com.br/desinformacao. Acesso em: 15 ago. 2019.

PAVEAU, Marie-Anne. É preciso repolitizar a Análise do Discurso recolocando-a numa perspectiva materialista. In: OLIVEIRA, Guilherme Adorno de et al. (org.). Encontros na Análise de Discurso: efeitos de sentidos entre continentes. Campinas/SP: Editora Unicamp, 2019.

PÊCHEUX, Michel. Ideologia - aprisionamento ou campo paradoxal? In: Michel Pêcheux. Análise de Discurso: Michel Pêcheux. Textos escolhidos por Eni Orlandi. Campinas/SP: Pontes, 2011.

PÊCHEUX, Michel. O enunciado: encaixe, articulação e (des)ligação. In: CONEIN, Bernard et al. (orgs.). Materialidades discursivas. Campinas/SP: EdUnicamp, 2016.

PÊCHEUX, Michel. O discurso: estrutura ou acontecimento. 7. ed. Campinas/SP: Pontes, 2015a.

PÊCHEUX, Michel. Papel da memória. In: ACHARD, Pierre et al. (org.). Papel da memória. Tradução de José Horta Nunes. Campinas/SP: Pontes, $2015 b$.

PÊCHEUX, Michel. Semântica e discurso: uma crítica à afirmação do óbvio. 5. ed. Campinas/SP: Editora Unicamp, 2014.

PIAGET, Jean. Biologia e conhecimento: ensaio sobre as relações entre as regulações orgânicas e os processos cognoscitivos. 2. ed. Petrópolis/RJ: Vozes, 1996.

RUSHKOFF, Douglas. Media virus!: hidden agendas in popular culture. Nova Iorque: Ballantine, 1994.

SALDAÑA, Paulo. Saiba como surgiu o termo 'ideologia de gênero'. Folha de S. Paulo, São Paulo, ano 98, n. 32.710, 23 out. 2018. Disponível em: https://www1.folha.uol.com.br/cotidiano/2018/10/saiba-como-surgiu-o-termo-ideologia-de-ge nero.shtml. Acesso em: 27 dez. 2018.

Recebido em: 23/09/2020; Aceito em: 05/03/2021. 